\title{
To Leave or Not to Leave: A Narrative Inquiry of Chinese EFL Teachers' Identity Evolution
}

\author{
Jianping Xie, Jinwei Dong \\ School of English and Education, Guangdong University of Foreign Studies, Guangzhou, China \\ Email: sallyxjp@gmail.com
}

How to cite this paper: Xie, J.P. and Dong, J.W. (2020) To Leave or Not to Leave: A Narrative Inquiry of Chinese EFL Teachers' Identity Evolution. Open Access Library Journal, 7: e7021.

https://doi.org/10.4236/oalib.1107021

Received: November 20, 2020

Accepted: December 19, 2020

Published: December 22, 2020

Copyright () 2020 by author(s) and Open Access Library Inc.

This work is licensed under the Creative Commons Attribution International License (CC BY 4.0).

http://creativecommons.org/licenses/by/4.0/

\begin{abstract}
Teacher identity evolves over time and is often characterized by crisis and destabilization. Based on self-reflection journals and in-depth interviews, this narrative inquiry explores the identity evolution and the accompanying contributive factors of identity crisis of three experienced Chinese EFL teachers in a higher vocational college in China over ten years, aiming to unveil the interactions between teachers' identity evolution trajectories and identity crisis factors. Findings show that, under the interplay of macro-level social factors, meso-level institutional factors, and micro-level personal factors, the three teachers' professional identities underwent from honeymoon phase during their early career years, to confusion phase and dilemma phase in the mid-career years featured by identity crisis. It is suggested that relevant parties should attach more importance and make efforts to scaffold Chinese EFL teachers' identity development during their mid-career phase in the particular L2 context of higher vocational college in China, so as to help them maintain high commitment to their professional identity and teaching throughout the whole career.
\end{abstract}

\section{Subject Areas}

Education, Linguistics

\section{Keywords}

Identity Evolution, Identity Crisis, Narrative Inquiry, Higher Vocational College EFL Teacher

\section{Introduction}

Identity, which refers to who or what someone is, the various meanings someone 
attaches to him/herself, and the meanings attributed by others (Beijaard, 1995) [1], is "diverse, contradictory, dynamic and changing over historical time and social space" (Norton \& Toohey, 2011, p. 417) [2]. Like any other types of identity, teacher identity is fluid and unstable which undergoes a "continuous revision and redefinition process" (Bolívar et al., 2014, p. 108) [3]. Teacher identity is a central component in teacher education initiatives (Yazan, 2017) [4] which impacts teacher development (Olsen, 2008) [5], teachers' teaching practice (Beijaard et al., 2004) [6], and teaching effectiveness (Ashforth \& Tomiuk, 2000) [7], and thus has received more and more attention in the academic circle. So far research on teacher identity mainly focused on pre-service or novice teachers, which generated rich insights on assisting pre-service or novice teachers' identity construction and development such as offering effective pre-service training, creating benign working environment, high salary, etc. (e.g., Liu \& Xu, 2011 [8]; Yazan, 2017 [4]; de Araujo Donnini Rodrigues, et al., 2018 [9]), whereas the sustainable identity development of the particular group of experienced teachers has generally been neglected over the years.

Given the dynamic nature of teacher identity, the journey of teacher identity evolution over an extended period of time can be bumpy with setbacks. In fact, teacher identity is characterized by crisis and destabilization (Bolívar, et al., 2014) [3]. Although identity crisis may, in some cases, promote the development of teacher identity (Bolívar \& Domingo, 2006) [10], more often it hinders one's professional identity development (Namaghi, 2009) [11] or even results in teachers' exodus from the teaching profession (Yang, 2005) [12]. Since identity crisis is "a recurring dilemma" (Bolívar, et al., 2014, p. 106) [3] which brings detrimental problem for teachers to maintain high commitment to their identities and profession, it is of great necessity to explore teacher identity evolution and unveil factors causing identity crisis during the course (ibid). However, in the extant literature, there is a lack of comprehensive and systematic investigation of contributive factors for teacher identity crisis and explorations of the interaction between identity crisis and identity evolution are still rare.

Among the multitude of research on language teacher identity, narrative inquiries (e.g., Farrell, 2011 [13]; Kanno \& Stuart, 2011 [14]; Liu \& Xu, 2011 [8]; Tsui, 2007 [15]; Johnson \& Golombek, 2011 [16]) form a major strand which have proven the effectiveness of narratives in organizing and recounting teacher identity experiences. The present study therefore carries on the narrative tradition and investigates three Chinese EFL teachers' identity evolutionary trajectories over a time span of over ten years in a higher vocational college in China, aiming to unveil the contributive factors of their identity crises and the interaction between identity crisis and identity evolution during the course. It is hoped that findings of this study provide implications for scaffolding experienced language teachers' sustainable identity development in China and other similar L2 contexts as well, and shed light on EFL teacher development and teacher education. 
The following will first review the extant literature on language teacher identity, identity evolution, and identity crisis, and then describe the methods of data collection and analysis of this study. Afterwards, the narratives of the three Chinese EFL teachers' identity evolution will be delineated in Section Four, followed by the discussions of the contributive factors for their identity crises in Section Five. The article will conclude by discussing implications for scaffolding language teachers' sustainable identity development.

\section{Literature Review}

\subsection{Language Teacher Identity}

The concept of "teacher identity" first emerged in the 1980s in the field of general education as an analytic notion for studying teaching and teacher education. Teacher identity is an ongoing and dynamic social process of how teachers interpret and reinterpret who they consider themselves to be and who they would like to become (Beijaard et al., 2004) [6] in relation to different ways of "inhabiting roles, positions, and cultural imaginaries" (Holland \& Lachicotte, 2007, p. 103) [17]. According to the literature, there are two common understandings of teacher identity: one is that teacher identity is not a static, invariant or unitary construct (e.g., Varghese, et al., 2005 [18]; Beijaard, Meijer, \& Verloop, 2004 [6]; Han, 2017 [19]) because it is based on the core beliefs one has about teaching and being a teacher, which are continuously changing and reformed through experience; The second is that teacher identity is a highly contextualized, socially defined phenomenon (Beijaard, Meijer, \& Verloop, 2004) [6] that "expresses personal practical knowledge gained in experience, learned contextually, and expressed on landscapes of practice" (Xu \& Connelly, 2009, p. 223) [20]. That is to say, teachers develop their identity in a context that brings social and cultural forces to bear upon that development (Holland \& Lachicotte, 2007) [17].

There has been a burgeoning interest in language teacher identity since the past decade (e.g., Beauchamp \& Thomas, 2009 [21]; Day \& Kington, 2008 [22]; Han, 2017 [19]; Tsui, 2007 [15]). It is shown that language teachers negotiate and construct identity under the interplay of 1) personal factors, such as teacher emotion (Xu, Y., 2013) [23], teachers' own English proficiency (Richards, 2008) [24], teaching beliefs and attitudes (Farrell, 2011) [13], or critical life events (Liu, 2009) [25]; 2) institutional factors like work environment (Miller, 2004) [26], teachers' relationships with stakeholders (administrators, colleagues, parents and students) (Kanno \& Stuart, 2011) [14], and 3) social factors like national language policy and reform (Liu \& Xu, 2011) [8]. These multidimensional factors shape the kaleidoscopic nature of language teacher identity. That is to say language teachers' identity contains social and individual elements simultaneously (Han, 2017) [19] which is influenced not only by one's life experiences, family background and values, education, peronality but also by what they do in relation to social discourses, policies, students and parents, their colleagues and their practices (ibid). However, how these factors influence teacher identity evo- 
lution and how they might result in teacher identity crisis over an extended period of time are relatively underexplored.

\subsection{Identity Evolution and Identity Crisis}

Huberman et al. (1993) [27] identified three career phases of teachers: 1) Year 1 - 3 career entry and early beginnings (feeling one's way), 2) Year 4 - 6 stabilization which has profound implications for twenty-five years, and 3) (serene or bitter) disengagement. So far, teacher identity construction at the beginning career phase received much attention as discussed earlier, and studies on teacher identity evolution across the three phases are rare. Among the few relevant studies, Day and Kington (2008) [22] studied 300 secondary and primary school teachers in England over four years and found that teachers in different career phases experienced different scenarios that challenged their abilities to sustain their initial commitment. The four-year longitudinal case study of four Chinese EFL teachers by $\mathrm{Xu}, \mathrm{H}$. (2013) [28] revealed their professional identities change in the first years of teaching in K-12 schools under the mixed influences of the institutional contexts of school and the dynamic educational contexts. These studies show that teacher identity changes across career phases, however, the complicated process of teacher identity evolution still needs further exploration.

The term identity crisis was coined by German psychologist Erik Erikson (1968) [29] to describe adolescents' failure to achieve ego identity when facing dramatic physical and mental change. Focused examination on teacher identity crisis is scarce until now (Xun \& Zheng, 2014) [30], but the handful relevant studies do suggest that teacher identity crisis can be triggered by factors such as work overload (Hargreaves, 1994) [31], educational reform (Bolívar, et al., 2014) [3], non-nativeness for language teachers (Shin, 2007) [32], or work environment and low payment (Yang, 2005) [12]. For instance, Shin (2007) [32] found the "English-only policy" which legitimizes NS as ideal language teachers led to identity crises in some NNS teachers in Korea. Bolívar, et al. (2014) [3] revealed that education reform destabilized the professional practice of 10 secondary teachers in Spain and brought about their identity crisis. Similarly, Zhang and Lam (2008) [33], using an experienced Chinese secondary school teacher of physics as example, pointed out that teachers who feel powerless to adapt to the new mode in the curriculum reform would experience identity crisis.

Given the multifaceted nature of teacher identity, more work is still needed to understand how various internal and external elements contribute to language teachers' identity crisis in a particular L2 context as well as how these factors shape language teachers' identity evolution over time. Therefore, this study targets at three Chinese EFL teachers in a higher vocational college in China, and specifically addresses three questions: 1) How did their professional identities evolve over the past ten years? 2) Have they experienced identity crisis over the past ten years? If yes, what are the contributive factors? and 3) How do these factors influence their teacher identity evolution? 


\section{Methodology}

\subsection{Narrative Inquiry}

This study took a narrative approach to explore the three Chinese EFL teachers' identity evolution trajectories, given that teacher identity is closely tangled with teacher experience and narrative is "the best way of representing and understanding experience" (Clandinin \& Connelly, 2000, p. 18) [34]. However, as Bolívar (2002) [35] pointed out, while narrative inquiry respects the voices of the investigated subjects, this advantage can bring problems to researchers. That is, if the researcher respect the subjects' emic discourses excessively, the researcher's interpretation may get caught inside the horizons of the subjects. To prevent this problem, researchers need to integrate both the emic (from within) and the etic (from outside) perspectives when interpreting and reconstructing the narratives to portray the inner realities inscribed in the external context that provides meaning for the realities.

\subsection{Participants}

The three participants Linda, Shelly, and June (in pseudonyms) are full-time college English teachers in College A, a public vocational college in China. There are over 40 English teachers in College A, and most of them are Chinese EFL teachers who teach compulsory public English courses to Year-1 non-English major students. The three teachers were chosen because they are experienced who had been teaching in College A for over ten years by the time this study started. Second, they are representative of the English staff in education background (BAs in English, domestic MAs, and MA overseas returnees) and age group (late 40s, early 40s, and late 30s) (see Table 1 for the basic information of the participants). Also, one of the researchers (Researcher A henceforth, the other Researcher B) studied with the three teachers at a short-term training project and has maintained friendship with them since then for over a decade, so the strong rapport ensures access to their private inner stories.

\subsection{Data Collection}

The narratives of Linda, Shelly, and June were constructed and reconstructed over one year mainly based on their self-reflection journals and two rounds of in-depth interviews.

The three teachers were first invited to write self-reflection journals to recount their 1) feelings and perceptions of being an English teacher in College A over

Table 1. Basic information of the participants.

\begin{tabular}{cccc}
\hline Name & Education background & Age & $\begin{array}{c}\text { Teaching experience in } \\
\text { College A by 2017 }\end{array}$ \\
\hline Linda & MA in English, domestic & Early 40s & 11 years \\
Shelly & MA in Business Management, overseas & Late 30s & 10 years \\
June & BA in English, domestic & Late 40s & 16 years \\
\hline
\end{tabular}


the years; satisfaction with the profession; perceptions of their status and social recognition; relationship with the institutional environment (the school, students, colleagues); and attitudes toward socio-institutional policies and management, curriculum reform, etc.; and 2) any significant events and meaningful anecdotes of teaching, research, and life relevant to such feelings, perceptions, attitudes, and evaluations. They were given a whole winter holiday (Feb. 2017) for the writing and there were no word limits nor requirements about language or structure of the writing. They all wrote the journals in chronological order and Chinese.

After obtaining insights from their journals, Researcher A conducted two rounds of one-to-one and face-to-face semi-structured interviews with the teachers. The first round was undertaken in July 2017 during which the teachers were invited to elaborate on what they mentioned in the journals, so that the researchers could gain more insights into the teachers' reflections and story characters, plots and contexts (Clandinin \& Connelly, 2000) [34]. The second round was conducted one month later which involved more sensitive talks about the socio-institutional and personal factors (e.g., collegial relationship, family incidents or plans) or critical events that affected their identity experiences. Each interview took about two hours and was recorded with their permission. Then the interviews were transcribed verbatim in Chinese.

\subsection{Data Analysis}

A qualitative thematic analysis of the data was carried out, which was interwoven with data collection. First, a "preliminary exploratory analysis" (Creswell, 2005, p. 237) [36] was undertaken. Both researchers first read through their narratives several times to obtain a general understanding. Then major recurring themes and categories were identified and manually coded. As discussed earlier, bothemic and etic views are necessary for interpreting subjects' narratives. Researcher A'spersonal close friendship with the teachers over the years kind of gives her a double identity of "insider" and outsider, which, though in some way opened an opportunity to a unusual access to the meaning reconstruction (Liu \& $\mathrm{Xu}, 2011)$ [8] of the teachers' narratives, might bring subjectivity into the interpretation that can soften her judgment or even "mute the emic voice" if untamed (Peshkin, 1988, p. 21) [37]. To avoid this potential problem, the preliminary analysis and coding were carried out by both researchers independently. Then both researchers discussed and recoded those disagreed places.

Three thematic phases of the teachers' identity evolution emerged from the preliminary analysis: the honeymoon phase (characterized by meaning constructs like happiness, satisfaction, luckiness, etc.), the confusion phase (characterized by loss, disappointment, hopelessness etc.), and the dilemma phase (characterized by struggle, indecisiveness, predicament, etc.). To group the categories that contributed to thesethematic phases, Day's (2011) [38] categorization of the macro-, meso-, and micro-level influential factors of teacher identity were ap- 
plied as a guiding compass: 1) socio-culturallpolicy, reflecting cultural, social and political expectations of teachers and teaching, as well as teachers' educational ideals, and ethical and moral purposes; 2) workplace or socially located influences, including the micro-politics and social relationships of school, department or classroom contexts and local conditions (pupil behavior, the quality of leadership, and support and feedback in teachers' immediate work context); and 3) personal influences, located in life outside school like personal history, present life, family, and a personal sense of efficacy and vulnerability. This preliminary analysis revealed contributive factors to the three teachers' identity experiences from the above three levels: curriculum reform, college and school policy on teaching, collegial cooperation, classroom satisfaction, research, students, promotion of professional title, personal life experience, etc. The thematic phases and the contributive factors formed the guiding coding scheme for the later main coding, as shown by Figure 1.

The actual main coding was implemented with the assistance of Nvivo 10. The reflective journals and interview transcripts were imported into the software and coded according to the coding scheme as shown above. This round of coding also, to some extent, "triangulated" (Liu \& Xu, 2011, p. 184) [8] the themes and categories derived from the manual coding, through which several new categories (such as family situation, teacher appraising system, social status) were

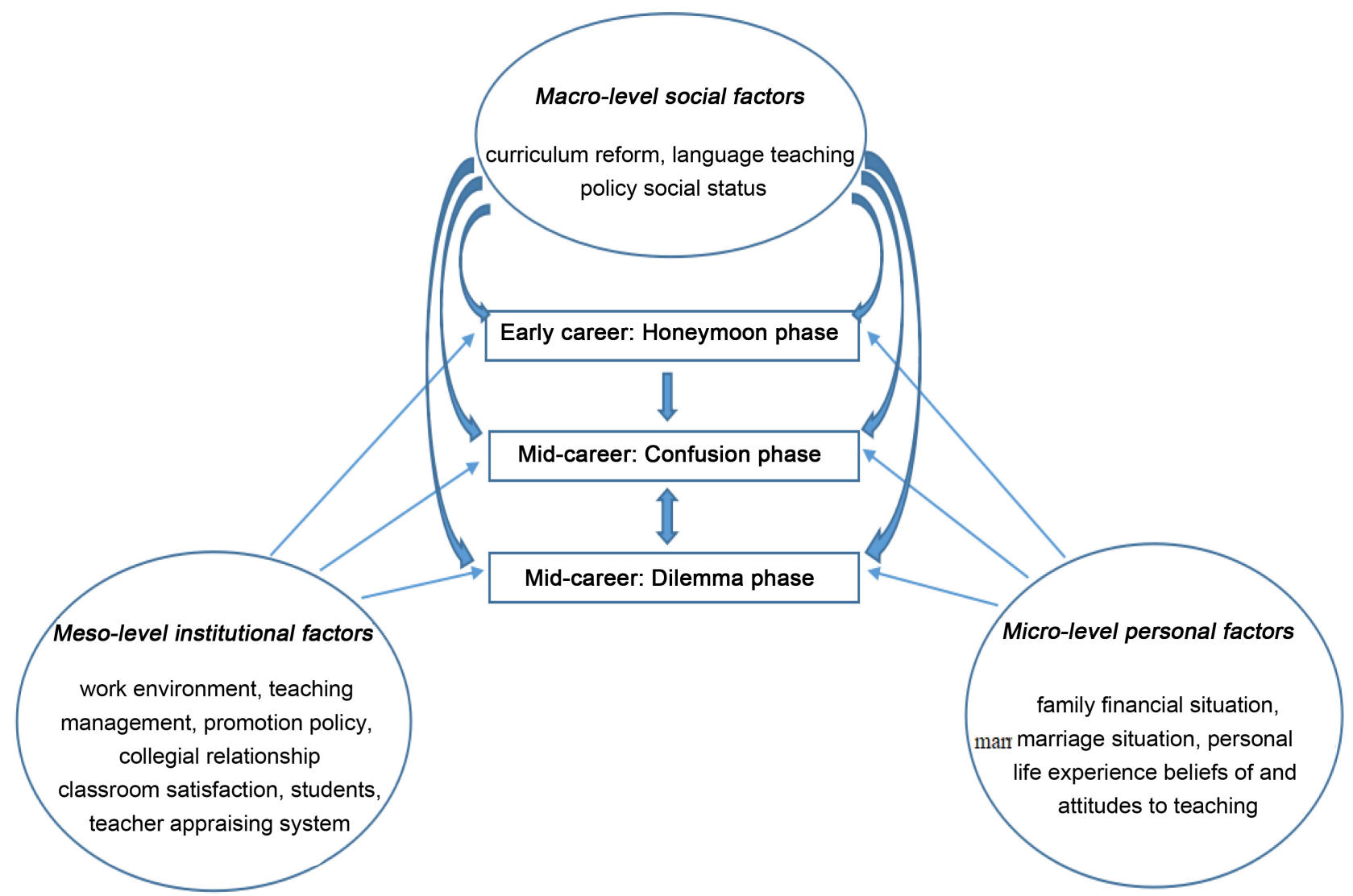

Figure 1. Coding scheme for the three Chinese EFL teachers' identity evolution. 
identified and added. Finally, the teachers' narratives were rewritten with the three thematic phases of identity evolution functioning as the storyline. Mini-stories concerning different influencing factors were recounted and weaved under the three phases. The reconstructed narratives of Linda, Shelly, and June were sent back to them to ensure the narratives reflected their experiences (Creswell, 2012) [39].

\section{Narratives of the Chinese EFL Teachers' Identity Evolution}

\subsection{Case Stories}

A brief sketch of each of the three teachers' "personal and contextual contours" (Xu, Y., 2013, p. 380) [23] will be presented here to help readers better understand their identity evolution over the years.

Linda was born in mid 1970s in a countryside of an underdeveloped province in China. Being the middle child in her family, she often played the role of "mother" who did most of the housework due to her mother's poor health condition. She first taught in a local primary school, during when she got married and had a son. Several years later, she went to an economically advanced city in China where she self-studied English and obtained a college diploma. To reunite with her husband who then moved to City A, Linda took the postgraduate entrance exam twice and was finally admitted by a university in City A, majoring in English Education. After she gained her master degree, Linda found the job in College A in 2006.

Born in early 1980s, Shelly's journey of academic pursuit was smoother than Linda's, who studied in City A from kindergarten to college. Though Shelly is a city girl, the financial condition of her family had never been sound as her father passed away long ago and all life burden fell onto her mother who ran a small grocery store. After gaining her BA of English, Shelly studied at a university in UK majoring in Business Management for a master degree. After graduation, she came back to City A and first worked in a private college and then a year later transferred to College A in 2007.

June has been teaching in College A for the longest time among the three. She was born in early 1970s in a countryside family in an inland province and similar to Linda, she shouldered much family responsibilities since childhood. After obtaining her BA of English from a four-year normal university in City A, she became a teacher in College A which was then a secondary vocational school. When Researcher A first met June in 2006, June was already an established figure in the school as one of the few associate professors in the English faculty of College A.

\subsection{Identity Evolution Trajectories}

Under the interplay of various macro-, meso-, and micro-level factors (as will be explicated in the next section), Linda, Shelly, and June's teacher identity evolu- 
tion in College A displayed a similar pattern over the past ten years: first the honeymoon phase during which they accepted being a higher vocational college English teacher, then the confusion phase when they doubted the meaning and value of that identity, and finally the dilemma phase during which they struggled over staying in or out of that identity.

\subsection{1. "At Least I Am Well-Paid!": Honeymoon Phase}

During the beginning years in College A, the three teachers were busy adapting to the work environment: getting familiarized with the curriculum and the school policies, preparing for the new lessons, learning to fit in the collegial community, dealing with the students, etc. To them, everything around was new and unset, and they were generally happy about their identities.

Linda cherished her job very much in the beginning years because it enabled her reunion with her family in City A:

When I got the job in College A, I was happy and satisfied ${ }^{1}$ because the job enabled me to settle down with my family in the city after all those years' hardships. I knew teaching vocational college students can be challenging, because they were not "good" students. Still, "I am a college teacher!” I told myself. The pay was also good! "What could I expect more?" I thought. So I worked hard and spent much time preparing the lessons though the students couldn't respond well at the class due to their low English proficiency.

In China, the under-achievers in Gaokao, China's annual unified college entrance exam, usually enter higher vocational and technical colleges for associate college degree. Different from some western countries like Germany where vocational education receives high appreciation, higher vocational colleges in China are commonly considered as "inferior" to the four-year universities. But for Linda, the high salary offset this disadvantage.

Unlike Linda, teaching in College A was not the desirable job for Shelly from the beginning, who seemed to have a strong desire to be a professional rather than a public course teacher:

It's not my dream job from the beginning as I wanted to teach professional course relating to my MA major! But my mum hoped me to have a stable job in College A: Apublic college! And strings were even pulled for me to enter College A. Therefore, how could I complain about the job then?

But after an "inner weighing" of the advantages and disadvantages of teaching in College A, Shelly accepted herself being a public college English teacher, who also mentioned salary as one reason:

Though College A is a vocational college, it's not easy to get a job in this school, given the fierce competition in the job market. Besides, the salary

${ }^{1}$ The bolded words in the excerpts of the teachers' narratives throughout the paper implicate that they are emphasized by the teachers either in tone, gesture, repetition, or other ways. 
was not bad in the first years, so I thought I could do the job for some years and then see how it would go.

College A was a secondary school when June first came and one year later it was upgraded to a higher vocational college. With the amelioration of the school, June' identity also underwent a sort of upgrade. This change exerted a positive influence on her at the beginning years, who joyfully embraced the new identity of being a college teacher:

After the school became a higher college, I felt especially lucky but also a bit nervous, because I knew I should adapt to the new identity. Therefore, I started to do research as a college teacher should do and published several papers on prestigious journals. That gained me lots of confidence. However, I soon noticed the school hadn't adjusted itself in administration. Nevertheless, I looked at the positive side and believed things would turn better gradually.

From the above, we can see that all the three teachers were aware of the imperfection of their job from the very beginning, However, they generally held positive attitudes towards the job with the appealing salary being one major reason, which seems have triumphed all other disadvantages (e.g., students' low English proficiency, school administration) and enabled them appreciate their identities. This proves that the financial element plays an important part in teacher identity construction and appreciation, especially for people like Linda, Shelly and June who experienced hardships and financial problems in the past.

\subsection{2. "Am I a College Teacher?": Confusion Phase}

After several years of teaching, the three teachers entered the mid-career phase who became familiarized with the institutional environment. However, they started to doubt the meaning of what they do as vocational college English teachers. That is, they all experienced identity crises.

Linda recalled a story which propelled her to rethink herself as a vocational college English teacher:

During one summer holiday, I attended a national conference about college English teaching. At one group discussion session, other teachers, who were mostly from four-year colleges and universities, shared their opinions with great enthusiasm and confidence. But I felt embarrassed as I had little to share. For the first time, it hit me that I and other undergraduate college teachers were so different.

Linda elaborated in the interview: "What I do for my job is mere repetition of teaching and I no longer have the passion for research! But I should enjoy the work like them!" She also confessed that she had felt lost in her job for a long time: "I felt I was a mere teaching machine with no goa!" 
Shelly also experienced identity crisis since her fourth year, whose perplexity mainly originated from her low job satisfaction and frustration of not being able to teach what she is most adept at, leading her to question the value of herself:

After three years' teaching the same stuff, I grew really bored. I got little satisfaction from the job. I studied Business Management, but what I have been teaching has nothing to do with it. I couldn't offer my students what I am most adept at. Andit's really difficult to teach the students English due to their weak foundation and the big class size. There's little room for free play due to the unified assessment for all classes! What's the meaning of being a teacher like this?

June's identity crisis mainly resulted from her disappointment with the college administration and the bleak prospect for her career development.

After working in College A for over five years, I realized things wouldn't change much in the college. I never felt appreciated and respected here! The administrative staff enjoy higher status than us. And there is little chance I obtain a higher professional title here. Even if I became a professor, I wouldn't be treated like a real professor as in those four-year colleges and universities. So, what's the point of doing the work then?

June defined being "a real professor" as "learned teachers with high achievements in teaching and research and are highly respected by the school." and said "In Colleges A, professors have little say and are not duely valued!"

At the confusion phase, the three teachers lost their previous zest for their work and doubted themselved. Linda's self-diffidence, Shelly's inner conflict, and June's deep disappointment are all symptoms of professional identity crisis as pointed out by Sadovnikova et al. (2016) [40].

\subsection{3. "To Leave or Not to Leave?": Dilemma Phase}

Identity crisis is a transitional point from which one either seeks way out or stays until degradation (Sadovnikova et al., 2016) [40]. Being aware of the career stagment, the three teachers started to find ways to deal with this undesirable situation since the past two or three years. All of them thought of exodus as a way to get out of being who they are and doing what they do. However, due to various reasons, they all faced some kind of dilemma: to leave or not to leave.

Linda thought of pursuing a doctorate degree to leave the school. However, as a woman who is used to put family first, she found herself in a dilemma between career and family:

I hoped to teach in a four-year college, and one possible way is to pursue a higher degree. Then I had to give this thought up because I thought of my son and my family who need my constant care. So, there seemed no way 


\section{out for me!}

Shelly also thought of pursuing the doctorate degree for a change. Unfortunately, College A's policy on staff continuing education and her family financial situation left her in a plight:

The job became more and more unbearable since the past several years, so I realized I need to do something! I wanted to pursue a doctorate degree at abroad. But then I got to know that this college doesn't allow the staff for full-time degree study. So it left me at a dilemma: To stay or to quit! If I quit, I will have financial problems; if I stay, I know I won't be happy with the work.

For June, the recent bad commute situation she emphasized is simply the last straw on her pile of disappointment with the job which propelled her into the idea of leaving the profession. But the retirement pension issue made her hesitant:

The thought of leaving the job grew stronger and stronger in the past three or four years, especially since I had to spend four or five hours a day on commute to the new suburban campus! I sometimes even laughed at myself at my age spending so much time on something I enjoy so little! So it dawned on me: Why not quit the job? But then I grew hesitant because if I quit on my part, I wouldn't receive full retirement pension as I was told.

The dilemma perplexed the three teachers for several years. Currently, Linda had her second child last year after the new two-child policy in China and her present life seems fully centered on her family. Shelly has started contacting overseas doctorate programs three years ago, but until recently, she is still in the preparation process. This overly prolonged process shows she is still troubled by her plight; June almost tendered her resignation letter one year ago, but at a recent meeting with Researcher A, she mocked herself as: "I still haven't decided yet?'

The trajectories of the three teachers' identity evolution over the past ten years, to some extent, resonate with Huberman's (1993) [27] model of teachers' career phases. That is, during the career entry phase, the three teachers experienced the exciting honeymoon phase of teacher identity. However, during the mid-career years, they all experienced entered the confusion and dilemma phases featured by identity crisis. Contributive factors for their identity crises will be explicated in the following.

\section{Contributive Factors for the Chinese Teachers' Identity Crises}

Drawing on Day's (2011) [38] categorization, this section will discuss the major contributive factors for Linda, Shelly, and June's identity crises from the mar- 
co-level dimension of social factors, meso-level dimension of institutional factors, and micro-level dimension of personal factors.

\subsection{Macro-Level Social Factors}

Recently, there has been a curriculum reform in higher vocational college English teaching since China's Vocational College English Curriculum Requirement (2009) promoted "General English (GE) + Professional English (PE)" as the new mode. GE aims at cultivating students' general English abilities of speaking, listening, reading, and writing and PE targets at English language competence relating to students' future profession. This new mode asks for Double-qualified teachers who not only have knowledge in English language and teaching but also other subject knowledge like accounting, logistics, tourism, etc., which poses challenges for mostvocational college English teachers, since the majority of them specialize in English language or English education and have no experience nor qualification in other disciplines.

This curriculum reform appeared repetitively in the teachers' narratives. The glim chance of becoming a double-qualified teacher made June to doubt her value to the school:

All they (the school administrative leaders) talked about now is "Double qualified teachers", making us feel that we are worthless to the school! They urged us to learn other professional knowledge, but our teaching workload was still as heavy as before. They offered us no help nor chance to access other fields. How could we find the extra time and energy? How could we transform into double-qualified teachers all by ourselves?

Shelly said the national propaganda for double-qualified teachers has put public English teachers in College A in a more unfavorable situation:

We public college English teachers are already peripheral members in the college compared with those professional course teachers. Now, with this "double-qualified teachers" thing going on, we became even more marginalized. The college already started to hire those who once worked in a professional field with good English proficiency. How could we survive?

Another reason mentioned by the teachers is the ongoing credit reduction of college English teaching in China. Due to the emphasis on the practical learning in vocational college education, the credits of public courses like college English are commonly reduced in recent years. In College A, the credits of college English decreased from 12 to 8, this made English teachers feel insecure about their job, as Linda remarked:

College English course is one of the "endangered" courses and always the victim in the reform. Whenever they need to cut the credits, they would think of public English first! We feel in peril here! 
The soundness of promoting double-qualified teachers and reducing public course credits is beyond the scope of the present discussion. But these broad social factors clearly exerted negative impact on the three teachers' identities, who felt powerless to adapt to the new requirement. This finding is consistent with the literature (e.g., Bolívar, et al., 2014 [3]; Zhang \& Lam, 2008 [33]; Van Lankveld et al., 2017 [41]), showing that the higher-up educational and curriculum reform could constrain teacher identity development if teachers are not well-prepared and assisted.

\subsection{Meso-Level Institutional Factors}

The institutional environment plays an unnegligible role in shaping teachers' identity (Tsui, 2007 [15]; Richards, 2008 [24]). Among the many aspects, those relating to the direct workplace, to teaching and students, and to staff development are found to be major contributors to the three teachers' identity crises.

\subsubsection{Direct Work Environment}

The immediate workplace of Linda, Shelly, and June is the school to which they are affiliated in College A. When invited to comment on the school community, Shelly recalled that she hadn't received much help when she was newly recruited and sought for guidance: "I was 'politely' turned down when I asked to observe other teachers' classes. I could only explore in the darkness, which was frustrating?' Linda shared an unpleasant incident which suggests a rather competitive environment:

I tutored one student to take part in a provincial Oral English Contest, who won the first prize. Normally I would receive the "Best Tutor" award for that. But I later found out on the certificate my name was the last among five names! I was the only teacher who actually tutored the student!

Linda continued to explain why this happened: tutoring students to win a provincial level contest can be one credential for teachers' promotion in professional titles. This incident led to Linda's deep disappointment with the school community as the leaders didn't consult her opinion on this matter at all.

When the work environment is perceived as collegial and supportive, it enhances teacher identity; when perceived as competitive, hierarchical, or lacking in trust, it constrains teacher identity development (Van Lankveld et al., 2017) [41]. Shelly and Linda's unhappy experiences discouraged them from feeling connected to the community with peer colleagues or forming a strong identity as a team member (Wenger, 1998) [42]. Shelly said she never grew the sense of belonging in the school while Linda's incident caused her to withdraw herself from the community who "stayed as less as possible in the staff office".

\subsubsection{Teaching and Students}

Schutz and Lee (2014, p. 174) [43] said: "In English language class, teachers 
may feel frustrated when students' performance did not reach teachers' academic goals for their outcomes. In this situation, teachers might reconsider their teacher identity, by asking themselves: 'can I do good job as an English teacher?"”. Teaching experience is particularly crucial in shaping teacher identity (Beauchamp \& Thomas, 2009) [21]. However, the three teachers reported low sense of achievement from their teaching due to students' general low English proficiency and large class size (60 - 120 students in a class). Consequently, they felt burned out after years of frustration with students. Moreover, teachers in College A have no access to students' appraisal of their teaching performance. "This means we will never know whether we are doing a good job or not!" said June. Students' evaluation score is a direct way for teachers to know students' feedback about the teaching. Favorable feedback makes teachers feel satisfied and fulfilled, which will in turn strengthen their teacher identities (Van Lankveld et al., 2017) [41]. Being denied from students' feedback, the teachers felt unmotivated with their teaching.

Additionally, Shelly mentioned College A's teaching regulations. One is that teachers are not allowed to play videos or songs at the class. "This rule needs to be flexible to language teachers, because we often need to use English videos or songs to facilitate teaching", Shelly said. Similarly, June said: "We are like employees in a private company being constantly monitored by the boss!" These indicate that some teaching rules in College A aroused negative emotions among the teachers that are detrimental to their identity appreciation.

\subsubsection{Staff Development Policy}

Teaching and research are two major parts for college teachers' professional development. Heavy teaching workload is one constraining factor for the teachers who have to work 16 - 24 teaching hours a week in average. Besides, they still need to meet some research requirement if they seek promotion in professional titles. This is challenging for them because they pointed out that they lack time and energy for research given their heavy teaching workload and lack of institutional support. Under such circumstances, they felt hopeless in career development, which in turn impeded their commitment to the job.

College A's unfavorable policy on staff development also seem to contribute to their identity crises. For instance, Shelly had to face the difficult choice of quitting the job or not in order to pursue her doctorate degree study. This unsupportive policy makes the teachers feel untrusted, as Shelly said: "The college doesn't encourage staff development or trust us, that's why they made this policy."

When teachers see limited professional development possibilities, the potential to envision themselves as senior teachers in the future will be curtailed, which would lead to exodus from the profession. This partly explains why the three teachers thought of leaving the job as a way out. 


\subsection{Micro-Level Personal Factors}

There is a developing awareness of connections between teachers' private lives and their professional thoughts and actions (Goodson, 2003) [44]. An important self of teachers are family situated, therefore, family situation, family plan or family change can influence teacher identity development. In Linda's case, family responsibility caused her to give up her own career pursuit, and the second child distracted her attention even changed her understanding of teaching: " $I$ now see myself mainly as a mother and less as a teacher! Teaching may not be as important as I used to think."

Similarly, Shelly's family financial situation puts her in a predicament, which also drove her into a prolonged preparation for leaving the college. June had a divorce one year ago which seemed changed her way of looking at teaching drastically: "The divorce made me realize that I don't need to be fully devoted toteaching, there are more important things." Clearly, June's case resonates with what Liu (2009) [25] found that dramatic occurrences in one's private life exert great influence on teacher identity shifts.

\section{Conclusions}

This study delineates the identity evolutionary trajectories of three Chinese EFL teachers in a higher vocational college in China, who underwent the honeymoon phase during early career years to confusion and dilemma phases during mid-career years and experienced identity crisis under the interactions of macro-level social factors, meso-level institutional factors, and micro-level personal factors. This study also shows that experienced language teachers are also vulnerable to identity crisis during the mid-career phase, which is detrimental to their identity development. Though the experiences of the three teachers cannot be unreasonably generalized, their experiences are representative to many mid-career language teachers in vocational colleges in China. Therefore, scaffolding language teacher identity development should be practiced not only on pre-service or novice teachers, but also continuously on experienced teachers, so as to help teachers maintain high commitment to the teaching throughout the whole teaching career.

To scaffold language teachers' sustainable identity development throughout their mid-career phase, the following recommendations are raised. At the macro-level, systematic and practical support from the society and institutions should be provided before and when initiating a language teaching reform and collegiate support and cooperation are recommended to help teachers adapt to the reform; at the meso-level, creating and maintaining a supportive and teacher-empowering community environment, offering regular in-service training on research and teaching, and formulating encouraging policy on teacher career development and teacher continuing learning and education are suggested for language teachers' sustainable professional development; at the micro-level, it is 
advocated that trade unions for teacher create various on-line and off-line platforms for peer-assistance among teachers and offer professional psychological counselling for teachers in need to prevent or lessen the negative impact from teachers' family affairs and personal problems.

This narrative study, by revealing the dynamic process of language teacher identity evolution over time as well as the various factors resulting in their identity crisis, draws our attention to the group of experienced language teachers and provides implications for EFL teacher development and teacher education in China and other similar L2 contexts.

\section{Acknowledgements}

This work was supported by Guangdong University of Foreign Studies, China under 2019 Postgraduate Education Innovative Project Grant [19GWYJSCX-09] and 2020 Postgraduate Education Innovative Project Grant [20GWYJSCX-07].

\section{Conflicts of Interest}

The authors declare no conflicts of interest regarding the publication of this paper.

\section{References}

[1] Beijaard, D. (1995) Teachers' Prior Experiences and Actual Perceptions of Professional Identity. Teachers and Teaching. Theory and Practice, 1, 281-294. https://doi.org/10.1080/1354060950010209

[2] Norton, B. and Toohey, K. (2011) Identity, Language Learning, and Social Change. Language Teaching, 44, 412-446. https://doi.org/10.1017/S0261444811000309

[3] Bolívar, A., Domingo, J. and Pérez-García, P. (2014) Crisis and Reconstruction of Teachers' Professional Identity: The Case of Secondary School Teachers in Spain. The Open Sports Sciences Journal, 7, 106-112.

https://doi.org/10.2174/1875399X01407010106

[4] Yazan, B. (2017) "It Just Made Me Look at Language in a Different Way": ESOL Teacher Candidates' Identity Negotiation through Teacher Education Coursework. Linguistics and Education, 40, 38-49. https://doi.org/10.1016/j.linged.2017.06.002

[5] Olsen, B. (2008) How Reasons for Entry into the Profession Illuminate Teacher Identity Development. Teacher Education Quarterly, 35, 23-40.

[6] Beijaard, D., Meijer, P.C. and Verloop, N. (2004) Reconsidering Research on Teachers' Professional Identity. Teaching and Teacher Education, 20, 107-128. https://doi.org/10.1016/j.tate.2003.07.001

[7] Ashforth, B.E. and Tomiuk, M.A. (2000) Emotional Labour and Authenticity: Views from Service Agents. In: Fineman, S., Ed., Emotion in Organizations, Sage, Thousand Oaks, 184-203. https://doi.org/10.4135/9781446219850.n10

[8] Liu, Y. and Xu, Y. (2011) Inclusion or Exclusion? A Narrative Inquiry of a Language Teacher's Identity Experience in the "New Work Order" of Competing Pedagogies. Teaching and Teacher Education, 27, 589-597. https://doi.org/10.1016/j.tate.2010.10.013

[9] de Araujo Donnini Rodrigues, L., de Pietri, E., Santiago Sanchez, H. and Kuchah, K. 
(2018) The Role of Experienced Teachers in the Development of Pre-Service Language Teachers' Professional Identity. International Journal of Educational Research, 88, 146-155. https://doi.org/10.1016/j.ijer.2018.02.002

[10] Bolívar, A. and Domingo, J. (2006) The Professional Identity of Secondary School Teachers in Spain: Crisis and Reconstruction. Theory and Research in Education, 4, 332-339. https://doi.org/10.1177/1477878506069105

[11] Namaghi, S.A. (2009) A Data-Driven Conceptualization of Language Teacher Identity in the Context of Public High Schools in Iran. Teacher Education Quarterly, 36, 111-124.

[12] Yang, M. (2005) A Probe into the Self-Identity Crisis of Young Teachers in American Cities and Its Causes. Studies in Foreign Education, 32, 22-24.

[13] Farrell, T.S.C. (2011) Exploring the Professional Role Identities of Experienced ESL Teachers through Reflective Practice. System, 39, 54-62. https://doi.org/10.1016/j.system.2011.01.012

[14] Kanno, Y. and Stuart C. (2011) Learning to Become a Second Language Teacher: Identities-in-Practice. The Modern Language Journal, 95, 236-252. https://doi.org/10.1111/j.1540-4781.2011.01178.x

[15] Tsui, A. (2007) Complexities of Identity Formation: A Narrative Inquiry of an EFL Teacher. TESOL Quarterly, 41, 657-680. https://doi.org/10.1002/j.1545-7249.2007.tb00098.x

[16] Johnson, K.E. and Golombek, P.R. (2011) The Transformative Power of Narrative in Second Language Teacher Education. TESOL Quarterly, 45, 486-509. https://doi.org/10.5054/tq.2011.256797

[17] Holland, D.C. and Lachicotte, W. (2007) Vygotsky, Mead, and the New Sociocultural Studies of Identity. In: Daniels, H., Cole, M. and Wertsch, J.V., Eds., The Cambridge Companion to Vygotsky, Cambridge University Press, Cambridge, 101-135. https://doi.org/10.1017/CCOL0521831040.005

[18] Varghese, M., Morgan, B., Johnston, B. and Johnson, K.A. (2005) Theorizing Language Teacher Identity: Three Perspectives and Beyond. Journal of Language, Identity, and Education, 4, 21-44. https://doi.org/10.1207/s15327701jlie0401_2

[19] Han, I. (2017) Conceptualisation of English Teachers' Professional Identity and Comprehension of Its Dynamics. Teachers and Teaching, 23, 549-569. https://doi.org/10.1080/13540602.2016.1206525

[20] Xu, S. and Connelly, F.M. (2009) Narrative Inquiry for Teacher Education and Development: Focus on English as a Foreign Language in China. Teaching and Teacher Education, 25, 219-227. https://doi.org/10.1016/j.tate.2008.10.006

[21] Beauchamp, C. and Thomas, L. (2009) Understanding Teacher Identity: An Overview of Issues in the Literature and Implications for Teacher Education. Cambridge Journal of Education, 39, 175-189. https://doi.org/10.1080/03057640902902252

[22] Day, C. and Kington, A. (2008) Identity, Well-Being and Effectiveness: The Emotional Contexts of Teaching. Pedagogy, Culture and Society, 16, 7-23. https://doi.org/10.1080/14681360701877743

[23] Xu, Y. (2013) Language Teacher Emotion in Relationships: A Multiple Case Study. In: Zhu, X. and Zeichner, K., Eds., Preparing Teachers for the 21 st Century, Springer, Berlin, 371-393. https://doi.org/10.1007/978-3-642-36970-4 22

[24] Richards, J.C. (2008) Second Language Teacher Education Today. RELC Journal, 39, 158-177. https://doi.org/10.1177/0033688208092182 
[25] Liu, Y. (2009) Teachers' Identities in Personal Narratives. In: Bianco, J.L., Orton, J. and Yihong, G., Eds., China and English: Dilemmas of Identity, Multilingual Matters, Bristol, 255-267. https://doi.org/10.21832/9781847692306-017

[26] Miller, J. (2004) Social Languages and Schooling: The Uptake of Sociocultural Perspectives in School. In: Hawkins, M., Ed., Language Learning and Teacher Education, Multilingual Matters, Clevedon, 113-146. https://doi.org/10.21832/9781853597657-008

[27] Huberman, A.M., Grounauer, M.-M. and Marti, J. (1993) The Lives of Teachers. Cassell, London.

[28] Xu, H. (2013) From the Imagined to the Practiced: A Case Study on Novice EFL Teachers' Professional Identity Change in China. Teaching and Teacher Education, 31, 79-86. https://doi.org/10.1016/j.tate.2013.01.006

[29] Erikson, E.H. (1968) Identity, Youth, and Crisis. W.W. Norton and Company, New York.

[30] Xun, Y. and Zheng, X. (2014) A Review of the Studies on EFL Teachers' Identity in the Past Decade. Modern Foreign Languages, 37, 118-126.

[31] Hargreaves, A. (1994) Changing Teachers, Changing Times: Teachers' Work and Culture in the Postmodern Age. Cassell, London.

[32] Shin, H. (2007) English Language Teaching in Korea: Toward Globalization or Glocalization. In: Cummins, J. and Davison, C., Eds., International Handbook of English Language Teaching, Springer, New York, 75-86. https://doi.org/10.1007/978-0-387-46301-8 7

[33] Zhang, S. and Lam, C. (2008) Crisis and Reconstruction of Teacher Professional Identity in Curriculum Reform. Research in Education Development, 2, 41-44.

[34] Clandinin, D.J. and Connelly, F.M. (2000) Narrative Inquiry: Experience and Story in Qualitative Research. Jossey-Bass, San Francisco. https://doi.org/10.1016/B978-008043349-3/50013-X

[35] Bolívar, A. (2002) “De nobis ipse silemus?”: Epistemology of Biographical Narrative Research in Education. Revista Electrónica de Investigación Educativa, 4, 1-24.

[36] Creswell, J.W. (2005) Educational Research Planning, Conducting, and Evaluating Quantitative and Qualitative Research. Pearson, Upper Saddle River.

[37] Peshkin, A. (1988) In Search of Subjectivity-One's Own. Educational Researcher, 17, 17-21. https://doi.org/10.3102/0013189X017007017

[38] Day, C. (2011) Uncertain Professional Identities: Managing the Emotional Contexts of Teaching. In: Day, C. and Lee, J.C.-K., Eds., New Understandings of Teacher's Work: Emotions and Educational Change, Springer, Dordrecht, 45-64. https://doi.org/10.1007/978-94-007-0545-6 4

[39] Creswell, J.W. (2012) Educational Research Planning, Conducting, and Evaluating Quantitative and Qualitative Research. 4th Edition, Pearson, Boston.

[40] Sadovnikova, N.O., Sergeeva, T.B. and Suraeva, M.O. and Kuzminab, O.Y. (2016) Phenomenological Analysis of Professional Identity Crisis Experience by Teachers. Internation Journal of Environment and Science Education, 11, 6898-6912.

[41] Van Lankveld, T., Schoonenboom, J., Volman, M., Croiset, G. and Beishuizen, J. (2017) Developing a Teacher Identity in the University Context: A Systematic Review of the Literature. Higher Education Research and Development, 36, 325-342. https://doi.org/10.1080/07294360.2016.1208154

[42] Wenger, E. (1998) Communities of Practice: Learning, Meaning and Identity. Journal of Mathematics Teacher Education, 6, 185-194. 
https://doi.org/10.1017/CBO9780511803932

[43] Schutz, P.A. and Lee, M. (2014) Teacher Emotion, Emotional Labor and Teacher Identity. In: van den Hoven, P. and ten Thije, J.D., Eds., Utrecht Studies in Language and Communication, Vol. 27, Brill Publishers, Leiden, 169-184.

[44] Goodson, I. (2003) Professional Knowledge, Professional Lives: Studies in Education and Change. Open University Press, Maidenhead and Philadelphia. https://doi.org/10.4324/9780203453988 